medRxiv preprint doi: https://doi.org/10.1101/2020.08.27.20183442; this version posted September $12,2020$. The copyright holder for this preprint (which was not certified by peer review) is the author/funder, who has granted medRxiv a license to display the preprint in It is made available under a CC-BY-NC-ND 4.0 International license .

\title{
Tocilizumab in Hospitalized Patients With COVID-19 Pneumonia
}

Ivan O. Rosas, M.D., Norbert Bräu, M.D., M.B.A., Michael Waters, M.D., Ronaldo Go, M.D., Bradley D. Hunter, M.D., Sanjay Bhagani, M.D., Daniel Skiest, M.D., Mariam S. Aziz, M.D., Nichola Cooper, M.D., Ivor S. Douglas, M.D., Sinisa Savic, Ph.D., Taryn Youngstein, M.D., M.R.C.P., Lorenzo Del Sorbo, M.D., Antonio Cubillo Gracian, M.D.,

David J. De La Zerda, M.D., Andrew Ustianowski, Ph.D., Min Bao, M.D., Sophie Dimonaco, M.Sc., Emily Graham, Ph.D., Balpreet Matharu, M.D., Helen Spotswood, Ph.D., Larry Tsai, M.D., and Atul Malhotra, M.D.

Baylor College of Medicine, Houston, TX (I.O.R); James J. Peters Veterans Affairs Medical Center, Bronx, and Icahn School of Medicine at Mount Sinai, New York, NY (N.B.); eStudy Site, Chula Vista, CA (M.W.); Hacksensack University Medical Center, Hackensack, NJ (R.G.); Intermountain Healthcare, Salt Lake City, UT (B.D.H.); Royal Free Hospital, London, United Kingdom (S.B.); University of Massachusetts Medical School-Baystate, Springfield, MA (D.S.); Rush University Medical Center, Chicago, IL (M.S.A.); Imperial College London, London, United Kingdom (N.C., T.Y.); Denver Health Medical Center, Denver, and University of Colorado, Anschutz School of Medicine, Aurora, CO (I.S.D.); Leeds Teaching Hospitals NHS Trust and National Institute for Health Research-Leeds Biomedical Research Centre, Leeds, United Kingdom (S.S.); University Health Network, Toronto, ON, Canada (L.D.S.); Hospital Universitario HM Sanchinarro, Centro Integral, Oncológico Clara Campal and Departamento de Ciencias Médicas Clínicas, Facultad de Medicina, Universidad CEU San Pablo, Madrid, Spain (A.C.G.); University of Miami Miller School of Medicine, Miami, FL (D.J.D.L.Z.); North Manchester General Hospital, Manchester, United Kingdom (A.U.); Genentech, South San Francisco, CA (M.B., L.T.); 
medRxiv preprint doi: https://doi.org/10.1101/2020.08.27.20183442; this version posted September $12,2020$. The copyright holder for this preprint (which was not certified by peer review) is the author/funder, who has granted medRxiv a license to display the preprint in It is made available under a CC-BY-NC-ND 4.0 International license .

Roche Products Ltd, Welwyn Garden City, United Kingdom (S.D., E.G., B.M., H.S.);

University of California San Diego, La Jolla, CA (A.M.)

\section{Corresponding author:}

Ivan O. Rosas, M.D.

Professor and Section Chief

Pulmonary, Critical Care, and Sleep Medicine

Baylor College of Medicine

7200 Cambridge Street

Houston, Texas 77030

Phone: (832) 292-0055

Email: ivan.rosas@bcm.edu

Article Type: Original Research Article, Rapid Review

Words: 2696 (maximum 2700)

Figures/Tables: 2/3 (maximum 5)

Supplementary: 2 supplementary appendices, 2 supplementary tables, 4 supplementary figures

References: 24 (maximum 40) 
medRxiv preprint doi: https://doi.org/10.1101/2020.08.27.20183442; this version posted September $12,2020$. The copyright holder for this preprint (which was not certified by peer review) is the author/funder, who has granted medRxiv a license to display the preprint in It is made available under a CC-BY-NC-ND 4.0 International license.

\begin{abstract}
$<<250$ of maximum 250 words $>>$
\end{abstract}

\title{
BACKGROUND
}

COVID-19 is associated with immune dysregulation and hyperinflammation. Tocilizumab is an anti-interleukin-6 receptor antibody.

\section{METHODS}

Patients hospitalized with severe COVID-19 pneumonia receiving standard care were randomized (2:1) to double-blinded intravenous tocilizumab $8 \mathrm{mg} / \mathrm{kg}$ or placebo. The primary outcome measure was clinical status on a 7-category ordinal scale at day 28 (1, discharged/ready for discharge; 7, death).

\section{RESULTS}

Overall, 452 patients were randomized; the modified-intention-to-treat population included 294 tocilizumab-treated and 144 placebo-treated patients. Clinical status at day 28 was not statistically significantly improved for tocilizumab versus placebo $(\mathrm{P}=0.36)$. Median $(95 \%$ CI) ordinal scale values at day 28: 1.0 (1.0 to 1.0$)$ for tocilizumab and 2.0 (1.0 to 4.0 ) for placebo (odds ratio, 1.19 [0.81 to 1.76$]$ ). There was no difference in mortality at day 28 between tocilizumab (19.7\%) and placebo (19.4\%) (difference, $0.3 \%$ [95\% CI, -7.6 to 8.2]; nominal $\mathrm{P}=0.94$ ). Median time to hospital discharge was 8 days shorter with tocilizumab than placebo (20.0 and 28.0, respectively; nominal $\mathrm{P}=0.037$; hazard ratio 1.35 [95\% $\mathrm{CI} 1.02$ to 1.79]). Median duration of ICU stay was 5.8 days shorter with tocilizumab than placebo $(9.8$ and 15.5 , respectively; nominal $\mathrm{P}=0.045$ ). In the safety population, serious adverse events occurred in $34.9 \%$ of 295 patients in the tocilizumab arm and $38.5 \%$ of 143 in the placebo arm.

\section{CONCLUSIONS}


medRxiv preprint doi: https://doi.org/10.1101/2020.08.27.20183442; this version posted September 12, 2020. The copyright holder for this preprint (which was not certified by peer review) is the author/funder, who has granted medRxiv a license to display the preprint in It is made available under a CC-BY-NC-ND 4.0 International license .

In this randomized placebo-controlled trial in hospitalized COVID-19 pneumonia patients, tocilizumab did not improve clinical status or mortality. Potential benefits in time to hospital discharge and duration of ICU stay are being investigated in ongoing clinical trials.

Trial registration: ClinicalTrials.gov NCT04320615 
medRxiv preprint doi: https://doi.org/10.1101/2020.08.27.20183442; this version posted September $12,2020$. The copyright holder for this preprint (which was not certified by peer review) is the author/funder, who has granted medRxiv a license to display the preprint in It is made available under a CC-BY-NC-ND 4.0 International license .

Coronavirus disease 2019 (COVID-19) has rapidly developed into a global health threat since emerging in China in late 2019. ${ }^{1}$ Severe COVID-19 pneumonia, occurring in approximately $15 \%$ of patients infected with severe acute respiratory syndrome coronavirus-2 (SARS-CoV2), is associated with high mortality rates and places extensive burden on intensive care units to provide mechanical ventilation and other advanced forms of life support. ${ }^{2,3}$ Similar to Middle Eastern Respiratory Syndrome and SARS-CoV-1, ${ }^{4}$ an initial phase of COVID-19 with high viral replication precedes a second disease phase that may be driven by the host immune response. This can lead to rapid increase in proinflammatory cytokines, an uncontrolled inflammatory response, acute respiratory distress syndrome (ARDS), and multiple organ failure. ${ }^{4,5}$ Interleukin-6 levels correlate with COVID-19 severity, ${ }^{6,7}$ suggesting that, in this setting, immune dysregulation and ARDS might be influenced by interleukin- $6 .{ }^{5,8}$ Accumulation of lymphocytes and inflammatory monocytes, endotheliitis, apoptosis, thrombosis, and angiogenesis in the pulmonary vasculature of patients with COVID-19 suggests that vascular inflammation and dysfunction contribute to the pathophysiology of severe COVID-19 pneumonia. ${ }^{9,10}$ Interleukin-6 promotes endothelial dysfunction and development of vascular permeability and might play a role in the vascular dysfunction of this disease. ${ }^{11}$

The potential role of interleukin-6 in COVID-19 pneumonia ${ }^{5,8}$ provides rationale for investigation of interleukin-6 signaling inhibitors. Tocilizumab is a monoclonal antiinterleukin-6 receptor-alpha blocking antibody used to treat certain inflammatory diseases. ${ }^{12}$ Improvements in patients with severe COVID-19 pneumonia who received tocilizumab were observed in case reports ${ }^{13-15}$ and supported by retrospective observational cohort studies that showed rapid reduction in fever, reduced need for oxygen support and mechanical ventilation, and improvement in lung manifestations. ${ }^{16-21}$ 
medRxiv preprint doi: https://doi.org/10.1101/2020.08.27.20183442; this version posted September $12,2020$. The copyright holder for this preprint (which was not certified by peer review) is the author/funder, who has granted medRxiv a license to display the preprint in It is made available under a CC-BY-NC-ND 4.0 International license.

This is the first global, randomized, double-blind, placebo-controlled trial to investigate whether tocilizumab has clinical benefit in hospitalized patients with severe COVID-19 pneumonia.

\section{PATIENTS AND METHODS}

\section{Trial Design and Oversight}

COVACTA is a global, multicenter, randomized, double-blind, placebo-controlled, phase 3 trial investigating the efficacy and safety of tocilizumab in patients with severe COVID-19 pneumonia (ClinicalTrials.gov, NCT04320615). Patients 18 years or older with severe COVID-19 pneumonia confirmed by positive polymerase chain reaction test in any body fluid and evidenced by bilateral chest infiltrates on chest x-ray or computed tomography were enrolled. Eligible patients had blood oxygen saturation $\leq 93 \%$ or partial pressure of oxygen/fraction of inspired oxygen $<300 \mathrm{~mm} / \mathrm{Hg}$. Patients were excluded if the treating physician determined that death was imminent and inevitable within 24 hours or if they had active tuberculosis or bacterial, fungal, or viral infection other than SARS-CoV-2. Standard care per local practice (antiviral treatment, low-dose steroids, convalescent plasma, supportive care) was permitted; however, concomitant treatment with another investigational agent (except antivirals) or any immunomodulatory agent was prohibited. Informed consent was obtained for all enrolled patients. The study was conducted in accordance with the International Council for Harmonization E6 guideline for good clinical practice and the Declaration of Helsinki or local regulations, whichever afforded greater patient protection. The protocol was reviewed by institutional review boards or ethics committees.

Eligible patients were randomized (2:1) to receive intravenous tocilizumab ( $8 \mathrm{mg} / \mathrm{kg}$ infusion, maximum $800 \mathrm{mg}$ ) or placebo plus standard care using an interactive voice or web-based 
medRxiv preprint doi: https://doi.org/10.1101/2020.08.27.20183442; this version posted September $12,2020$. The copyright holder for this preprint (which was not certified by peer review) is the author/funder, who has granted medRxiv a license to display the preprint in It is made available under a CC-BY-NC-ND 4.0 International license .

response system and permuted-block randomization. Randomization was stratified by geographic region (North America, Europe) and mechanical ventilation (yes, no). If clinical signs or symptoms did not improve or worsened (defined as sustained fever or worsened ordinal scale clinical status), a second infusion could be administered 8 to 24 hours after the first. The primary analysis was performed at day 28 , and the final study visit occurred at day 60.

\section{Outcome Measures}

The primary efficacy outcome was clinical status assessed on a 7-category ordinal scale (1, discharged or ready for discharge; 2, non-intensive care unit [ICU] hospital ward, not requiring supplemental oxygen; 3 , non-ICU hospital ward, requiring supplemental oxygen; 4 , ICU or non-ICU hospital ward, requiring noninvasive ventilation or high-flow oxygen; 5, ICU, requiring intubation and mechanical ventilation; 6, ICU, requiring extracorporeal membrane oxygenation or mechanical ventilation and additional organ support; 7, death) at day 28. Clinical status was recorded at baseline and every day during hospitalization. Key secondary efficacy endpoints were clinical status at day 14 on the 7-category ordinal scale, mortality at day 28 , ventilator-free days to day 28 , time to improvement from baseline in $\geq 2$ categories on the 7-category ordinal scale, and time to hospital discharge (or ready for discharge [defined as normal body temperature and respiratory rate and stable oxygen saturation on ambient air or $\leq 2 \mathrm{~L}$ supplemental oxygen]). Other secondary endpoints included time to clinical failure defined as death, withdrawal during hospitalization, mechanical ventilation, or ICU transfer (for patients intubated or in the ICU at baseline, a 1-category worsening of clinical status was considered clinical failure); incidence of mechanical ventilation (among those not mechanically ventilated at randomization); incidence of ICU transfer (among those not in ICUs at baseline); and duration of ICU stay. Adverse events 
medRxiv preprint doi: https://doi.org/10.1101/2020.08.27.20183442; this version posted September $12,2020$. The copyright holder for this preprint (which was not certified by peer review) is the author/funder, who has granted medRxiv a license to display the preprint in It is made available under a CC-BY-NC-ND 4.0 International license .

were recorded according to Medical Dictionary for Regulatory Activities system organ class and preferred term.

\section{Statistical Analysis}

Efficacy was assessed in the modified-intention-to-treat (mITT) population (any randomized patients who received study medication) for the primary and secondary endpoints according to treatment assigned at randomization. Analyses were stratified by region and mechanical ventilation status at randomization except for some subgroup analyses, as specified. The primary endpoint compared distribution of the ordinal scale of clinical status between treatment groups using a nonparametric van Elteren test. The ratio of the odds of being in a better clinical status category for tocilizumab versus placebo was determined using a proportional odds model to give odds ratios and 95\% CIs. Data from the last available postbaseline assessment on the ordinal scale were used for patients who withdrew before day 28, and all deaths and hospital discharges were carried forward. Differences in mortality were analyzed using the Cochran-Mantel-Haenszel test, differences in the number of ventilatorfree days were assessed using the van Elteren test, and time-to-event secondary endpoints were assessed using a log-rank test with Kaplan-Meier plots produced (deaths were rightcensored for all time-to-event endpoints assessing improvement). Cumulative incidence plots were generated using the nonparametric Aalen-Johansen estimator, where death is a competing risk. Safety was assessed in the safety-evaluable population (all patients who received any study medication) according to treatment first received. An estimated mITT population sample size of 450 patients randomized to tocilizumab or placebo was determined to give $90 \%$ power for the primary endpoint using the van Elteren test and an assumed distribution of the ordinal scale (Appendix 2). If significance was met, mortality at day 28 would be tested at the $5 \%$ level, but no other adjustment for multiplicity was planned. 
medRxiv preprint doi: https://doi.org/10.1101/2020.08.27.20183442; this version posted September $12,2020$. The copyright holder for this preprint (which was not certified by peer review) is the author/funder, who has granted medRxiv a license to display the preprint in It is made available under a CC-BY-NC-ND 4.0 International license.

\section{RESULTS}

\section{Patients}

Overall, 479 patients from 9 countries (Canada, Denmark, France, Germany, Italy, Netherlands, Spain, United Kingdom, United States) were screened, 452 patients were randomized, and 438 received study treatment (Figure 1). The mITT population included 294 patients randomized to tocilizumab and 144 to placebo. The safety population included 295 and 143 patients, respectively, because 1 patient randomized to placebo received tocilizumab. Overall, 224 of 301 patients (74.4\%) randomized to tocilizumab and 108 of 151 patients (71.5\%) randomized to placebo completed the 28-day follow-up. Excluding those who died, 20 patients $(6.6 \%)$ from the tocilizumab arm and $14(9.3 \%)$ from the placebo arm discontinued before day 28; none discontinued because of safety reasons.

Baseline demographics and disease characteristics were generally balanced between treatment arms. Approximately $70 \%$ of patients in each arm were men; 176 patients $(59.9 \%)$ were white and $40(13.6 \%)$ were black in the tocilizumab arm compared with $76(52.8 \%)$ and $26(18.1 \%)$, respectively, in the placebo arm. Mean age was $60.9 \pm 14.6$ years in the tocilizumab arm and $60.6 \pm 13.7$ years in the placebo arm.

At baseline or any time during the study, lower proportions of patients in the tocilizumab than the placebo arm received steroids (106 [36.1\%] vs 79 [54.9\%]), antiviral treatment (87 [29.6\%] vs $51[35.4 \%])$, and convalescent plasma (10 [3.4\%] vs 6 [4.2\%]) (Table 1).

\section{Primary Outcome}


medRxiv preprint doi: https://doi.org/10.1101/2020.08.27.20183442; this version posted September $12,2020$. The copyright holder for this preprint (which was not certified by peer review) is the author/funder, who has granted medRxiv a license to display the preprint in It is made available under a CC-BY-NC-ND 4.0 International license .

The primary endpoint was not met; clinical status on the 7-category ordinal scale at day 28 was not statistically significantly improved for tocilizumab versus placebo (van Elteren $\mathrm{P}=0.36)$. Median $(95 \% \mathrm{CI})$ 7-category ordinal scale clinical status values at day 28 were 1.0 (1.0 to 1.0$)$ for tocilizumab and $2.0(1.0$ to 4.0$)$ for placebo; ordinal logistic regression odds ratio was 1.19 (0.81 to 1.76$)$ (Table 2, Figure S1). Missing data were minimal for the primary endpoint of clinical status for the mITT population (3.7\% tocilizumab, $2.1 \%$ placebo).

\section{Secondary Outcomes}

All P values for secondary endpoints are nominal because the primary endpoint was not met. Median $(95 \% \mathrm{CI})$ clinical status values on the 7-category ordinal scale at day 14 were $3.0(2.0$ to 4.0 ) in the tocilizumab arm and 4.0 (3.0 to 5.0) in the placebo arm (van Elteren $\mathrm{P}=0.05$; odds ratio 1.42 [0.99 to 2.05]) (Table 2, Figure S2A). Fifty-eight patients (19.7\%) in the tocilizumab arm and $28(19.4 \%)$ in the placebo arm died by day 28 (weighted difference, $0.3 \%$ [95\% CI $-7.6 \%$ to $8.2 \%$ ]; Cochran-Mantel-Haenszel $\mathrm{P}=0.94)$ (Table 2). The median $(95 \% \mathrm{CI})$ number of ventilator-free days was 22.0 (18.0 to 28.0$)$ with tocilizumab and 16.5 (11.0 to 26.0) with placebo (difference, 5.5 [ -2.8 to 13.0]; van Elteren $\mathrm{P}=0.32$ ) (Table 2). Median (95\% CI) time to improvement from baseline in $\geq 2$ categories on the 7-category ordinal scale was 14 days (12 to 17 ) in the tocilizumab arm and 18 days (15 to 28 ) in the placebo arm $(\log$ rank $\mathrm{P}=0.08$; Cox proportional hazards ratio 1.26 [95\% CI 0.97 to 1.64$])$ (Table 2, Figure 2A). Median (95\% CI) time to hospital discharge/ready for discharge was 20 days (17 to 27$)$ in the tocilizumab arm and 28 days (20 to nonevaluable) in the placebo arm ( $\log$ rank $\mathrm{P}=0.04$; Cox proportional hazards ratio 1.35 [1.02 to 1.79]) (Table 2, Figure 2B). Median duration of ICU stay was 9.8 days in the tocilizumab arm and 15.5 days in the placebo arm (difference, -5.8 days [95\% CI -15.0 to 2.9]; van Elteren $\mathrm{P}=0.05$ ) (Table 2).

Cumulative incidences of time to improvement in clinical status, time to hospital discharge/ready for discharge, and mortality are shown in Figure S3. 
medRxiv preprint doi: https://doi.org/10.1101/2020.08.27.20183442; this version posted September $12,2020$. The copyright holder for this preprint (which was not certified by peer review) is the author/funder, who has granted medRxiv a license to display the preprint in It is made available under a CC-BY-NC-ND 4.0 International license.

\section{Subgroup Analyses}

Among 122 patients with baseline ordinal scale category 3 and 133 patients with baseline category 4, odds ratios (95\% CIs) for improved clinical status at day 28 were 1.27 (0.48 to 3.37 ) and 1.59 (0.78 to 3.24), respectively; among 60 patients with baseline category 5 and 108 patients with baseline category 6 , odds ratios for improved clinical status were $1.10(0.38$ to 3.15 ) and 0.88 (0.44 to 1.78$)$, respectively (Figure $2 \mathrm{C}$, Figure S2B). There was no significant difference in clinical status on the ordinal scale at day 28 between tocilizumab and placebo among patients mechanically ventilated at randomization (median [95\% CI], 5.0 [3.0 to 5.0$](\mathrm{n}=111)$ vs 5.0 [4.0 to 6.0$](\mathrm{n}=54)$; odds ratio 1.04 [0.58 to 1.85$])$ or those not mechanically ventilated at randomization $(1.0[1.0$ to 1.0$](\mathrm{n}=183)$ vs $1.0[1.0$ to 1.0$](\mathrm{n}=90)$; odds ratio 1.34 [0.79 to 2.27]) (Figure S4).

The incidence of mechanical ventilation among patients not mechanically ventilated at randomization was $27.9 \%(51 / 183)$ in the tocilizumab arm and $36.7 \%(33 / 90)$ in the placebo arm (weighted difference, $-8.9 \%$ [95\% CI $-20.7 \%$ to $3.0 \%]$; Cochran-Mantel-Haenszel nominal $\mathrm{P}=0.14)$. The incidence of ICU transfer among patients not in ICUs at baseline was $23.6 \%(30 / 127)$ in the tocilizumab arm and 40.6\% (26/64) in the placebo arm (weighted difference, $-17.2 \%$ [95\% CI $-31.3 \%$ to $-3.0 \%]$; Cochran-Mantel-Haenszel nominal $\mathrm{P}=0.01$ ). In post hoc analysis, among patients not mechanically ventilated at randomization, 53 of 183 $(29.0 \%)$ in the tocilizumab arm and 38 of $90(42.2 \%)$ in the placebo arm experienced clinical failure (includes those who died, withdrew during hospitalization, were transferred to an ICU, or required invasive mechanical ventilation within 28 days of baseline, as defined in Methods) (hazard ratio 0.614 ; $95 \%$ CI 0.40 to 0.94 ; nominal $\mathrm{P}=0.03$ ).

\section{Safety}


medRxiv preprint doi: https://doi.org/10.1101/2020.08.27.20183442; this version posted September $12,2020$. The copyright holder for this preprint (which was not certified by peer review) is the author/funder, who has granted medRxiv a license to display the preprint in It is made available under a CC-BY-NC-ND 4.0 International license .

In the safety population, adverse events were reported in $77.3 \%$ of 295 patients in the tocilizumab arm and $81.1 \%$ of 143 patients in the placebo arm through day 28 (Table 3); serious adverse events were reported in $34.9 \%$ and $38.5 \%$, respectively. Fatal events occurred in 58 patients $(19.7 \%)$ in the tocilizumab arm and $28(19.6 \%)$ in the placebo arm through day 28. The most commonly reported cause of death was COVID-19 pneumonia. Adverse events of special interest for tocilizumab were generally balanced between treatment arms. No tocilizumab-treated patients experienced anaphylaxis. Seventy-six serious infections were reported in 62 patients $(21.0 \%)$ in the tocilizumab arm and 49 in 37 patients $(25.9 \%)$ in the placebo arm through day 28. Similar proportions of patients in each treatment arm experienced adverse events and serious adverse events through the clinical cutoff date of June 24, 2020 (Table S1).

\section{DISCUSSION}

COVACTA, the first randomized, double-blind, placebo-controlled trial of tocilizumab in COVID-19 pneumonia, included patients from 9 countries. The primary endpoint was not met; there was no significant difference between tocilizumab plus standard care and placebo plus standard care in clinical status assessed using a 7 -category ordinal scale at day 28 , and no mortality benefit was demonstrated. However, tocilizumab appeared to be safe, and potentially clinically meaningful benefits were identified in time to hospital discharge/ready for discharge and duration of ICU stay. Among patients not mechanically ventilated at randomization, fewer treatment failures (progression to mechanical ventilation, ICU admission, or death) occurred in tocilizumab-treated than placebo-treated patients. Because the primary endpoint of the study was not met, these findings require validation in additional studies. Adverse events, including those of special interest for tocilizumab (bleeding events, 
medRxiv preprint doi: https://doi.org/10.1101/2020.08.27.20183442; this version posted September $12,2020$. The copyright holder for this preprint (which was not certified by peer review) is the author/funder, who has granted medRxiv a license to display the preprint in It is made available under a CC-BY-NC-ND 4.0 International license .

hepatic events, cardiac events), were generally balanced between tocilizumab and placebo, and incidences of infections or serious infections were lower in the tocilizumab arm.

The design and conduct of clinical trials in patients with COVID-19 present unique challenges and limitations. The COVACTA study population was intentionally chosen to be heterogeneous with regard to patient characteristics, previous/concurrent treatments, and disease severity to allow assessment of potential benefit across a broad range of patients and to reflect real-world practice in the expanding pandemic. Despite this heterogeneity, the proportion of patients discharged or ready for discharge by day 28 was higher in the tocilizumab arm than the placebo arm across the baseline ordinal scale of clinical status categories, whereas no consistent pattern was observed for mortality. The lack of standardized treatment across study sites and countries is an important limitation of this study considering potential interactions with antivirals and steroids. More patients in the placebo arm than the tocilizumab arm received concomitant steroids, which might have created bias toward lower mortality in the placebo $\operatorname{arm}^{22}$; however, this imbalance is unlikely to have obscured a significant treatment effect because the mortality rate was similar between treatment arms regardless of steroid use and was higher in patients who received steroids in both treatment arms than in those who did not (Table S2). Since our study was initiated, standard care treatment and understanding of the natural history of COVID-19 and its associated complications have evolved substantially. Based on current knowledge, optimal endpoints for clinical trials and effective treatments are likely to be different for different stages of disease. Future trials should be more narrowly focused or much larger to allow for further stratification based on disease severity and other baseline characteristics.

Results of this study must be interpreted in the context of therapies for severe COVID-19. Among treatments for patients hospitalized with COVID-19 investigated in randomized controlled trials, dexamethasone reduced mortality in patients receiving 
medRxiv preprint doi: https://doi.org/10.1101/2020.08.27.20183442; this version posted September $12,2020$. The copyright holder for this preprint (which was not certified by peer review) is the author/funder, who has granted medRxiv a license to display the preprint in It is made available under a CC-BY-NC-ND 4.0 International license.

mechanical ventilation or supplemental oxygen at randomization, but not in patients not receiving respiratory support. ${ }^{22}$ Remdesivir shortened time to recovery, but there was no statistically significant difference in 14-day mortality. ${ }^{23}$ Clinical trials investigating potential treatments — including other antivirals, anti-inflammatories, other targeted immunomodulators (sarilumab, anakinra, baricitinib, canakinumab), anticoagulants, and antifibrotics (tyrosine kinase inhibitors) - are underway, ${ }^{24}$ but the urgent need for effective treatments remains. In the absence of a more effective therapy, treatments such as tocilizumab, which this study suggests might hasten recovery and decrease the need for intensive care without increasing the risk for infections, serious infections, or other adverse events, might be clinically useful, even without a demonstrated mortality benefit.

Additional studies are ongoing and might expand the findings of COVACTA and address outstanding scientifically and medically relevant questions regarding the risk/benefit profile of tocilizumab in COVID-19 in more narrowly defined patient populations and in conjunction with current treatments. 
medRxiv preprint doi: https://doi.org/10.1101/2020.08.27.20183442; this version posted September $12,2020$. The copyright holder for this preprint (which was not certified by peer review) is the author/funder, who has granted medRxiv a license to display the preprint in It is made available under a CC-BY-NC-ND 4.0 International license.

\section{Acknowledgments}

The first draft of the manuscript was prepared by Larry Tsai, M.D., with writing support provided by Sara Duggan, Ph.D., of ApotheCom, funded by F. Hoffmann-La Roche Ltd. The data were analyzed by Helen Spotswood, Ph.D., Sophie Dimonaco, M.Sc., and Emily Graham, Ph.D., funded by Roche. The study was funded by F. Hoffmann-La Roche Ltd and funded in part with federal funds received from the Department of Health and Human Services, Office of the Assistant Secretary for Preparedness and Response, Biomedical Advanced Research and Development Authority, under OT number HHSO100201800036C.

\section{Conflicts of Interest}

I.O.R. received a grant from Roche/Genentech during the conduct of the study; a grant and personal fees from Genentech outside the submitted work; and personal fees from Boehringer and Bristol-Myers Squibb outside the submitted work.

N.B.'s institution received grant support from Roche/Genentech during the conduct of the study.

M.W., M.S.A., N.C., I.S.D., S.S., T.Y., A.C.G., and D.J.D.L.Z. have nothing to disclose.

R.G. has received consulting fees from F. Hoffmann-La Roche outside the submitted work.

B.D.H. has received speaker bureau fees from Kite Pharmaceuticals outside the submitted work.

S.B. has received personal fees from Gilead Sciences, Roche, and ViiV Healthcare outside the submitted work. 
medRxiv preprint doi: https://doi.org/10.1101/2020.08.27.20183442; this version posted September $12,2020$. The copyright holder for this preprint (which was not certified by peer review) is the author/funder, who has granted medRxiv a license to display the preprint in It is made available under a CC-BY-NC-ND 4.0 International license .

D.S.'s institution received grant support from Roche/Genentech during the conduct of the study.

L.D.S. received nonfinancial support from F. Hoffmann-La Roche Ltd during the conduct of the study.

A.U.'s institution received grant support from Roche/Genentech during the conduct of the study, and he has received personal fees from Gilead Sciences outside the submitted work.

M.B. and L.T. received a grant from Biomedical Advanced Research and Development Authority for the COVACTA study; are employees of Roche/Genentech; and have filed a patent for a method of treating pneumonia, including COVID-19 pneumonia, with an IL-6 antagonist.

S.D. received a grant from Biomedical Advanced Research and Development Authority for the COVACTA study and is an employee and a shareholder of Roche Products Ltd.

E.G. and B.M. are employees of Roche Products Ltd.

H.S. is an employee and a shareholder of Roche Products Ltd.

A.M.'s institution received grant support from Roche/Genentech during the conduct of the study; he has received funding from the National Institutes of Health outside the submitted work and medical education from Merck and Livanova outside the submitted work.

\section{Data sharing statement}

Qualified researchers may request access to individual patient level data through the clinical study data request platform (www.clinicalstudydatarequest.com). Further details on Roche's criteria for eligible studies are available here (https://clinicalstudydatarequest.com/Study- 
medRxiv preprint doi: https://doi.org/10.1101/2020.08.27.20183442; this version posted September 12, 2020. The copyright holder for this preprint (which was not certified by peer review) is the author/funder, who has granted medRxiv a license to display the preprint in It is made available under a CC-BY-NC-ND 4.0 International license .

Sponsors/Study-Sponsors-Roche.aspx). For further details on Roche's Global Policy on the Sharing of Clinical Information and how to request access to related clinical study documents, see here

(https://www.roche.com/research_and_development/who_we_are_how_we_work/clinical_tri als/our_commitment_to_data_sharing.htm) 
medRxiv preprint doi: https://doi.org/10.1101/2020.08.27.20183442; this version posted September $12,2020$. The copyright holder for this preprint (which was not certified by peer review) is the author/funder, who has granted medRxiv a license to display the preprint in It is made available under a CC-BY-NC-ND 4.0 International license.

\section{REFERENCES}

1. World Health Organization. Coronavirus disease (COVID-19) pandemic. 2020. https://www.who.int/emergencies/diseases/novel-coronavirus-2019. Accessed August 24, 2020.

2. Guan WJ, Ni ZY, Hu Y, et al. Clinical characteristics of coronavirus disease 2019 in China. N Engl J Med 2020;382:1708-20.

3. Yang X, Yu Y, Xu J, et al. Clinical course and outcomes of critically ill patients with SARS-CoV-2 pneumonia in Wuhan, China: a single-centered, retrospective, observational study. Lancet Respir Med 2020;8:475-81.

4. Vabret N, Britton GJ, Gruber C, et al. Immunology of COVID-19: current state of the science. Immunity 2020;52:910-41.

5. Giamarellos-Bourboulis EJ, Netea MG, Rovina N, et al. Complex immune dysregulation in COVID-19 patients with severe respiratory failure. Cell Host Microbe 2020;10:9921000.

6. Aziz M, Fatima R, Assaly R. Elevated interleukin-6 and severe COVID-19: a metaanalysis. J Med Virol 2020 April 28 (Epub ahead of print).

7. Zhu J, Pang J, Ji P, et al. Elevated interleukin-6 is associated with severity of COVID-19: a meta-analysis. J Med Virol 2020 May 29 (Epub ahead of print).

8. Ruan Q, Yang K, Wang W, Jiang L, Song J. Clinical predictors of mortality due to COVID-19 based on an analysis of data of 150 patients from Wuhan, China. Intensive Care Med 2020;46:846-8. 
medRxiv preprint doi: https://doi.org/10.1101/2020.08.27.20183442; this version posted September $12,2020$. The copyright holder for this preprint (which was not certified by peer review) is the author/funder, who has granted medRxiv a license to display the preprint in It is made available under a CC-BY-NC-ND 4.0 International license.

9. Varga Z, Flammer AJ, Steiger P, et al. Endothelial cell infection and endotheliitis in COVID-19. Lancet 2020;395:1417-8.

10. Ackermann M, Verleden SE, Kuehnel M, et al. Pulmonary vascular endothelialitis, thrombosis, and angiogenesis in Covid-19. N Engl J Med 2020;383:120-8.

11. Pons S, Fodil S, Azoulay E, Zafrani L. The vascular endothelium: the cornerstone of organ dysfunction in severe SARS-CoV-2 infection. Crit Care 2020;24:353.

12. Rubbert-Roth A, Furst DE, Nebesky JM, et al. A review of recent advances using tocilizumab in the treatment of rheumatic diseases. Rheumatol Ther 2018;5:21-42.

13. Cellina M, Orsi M, Bombaci F, Sala M, Marino P, Oliva G. Favorable changes of CT findings in a patient with COVID-19 pneumonia after treatment with tocilizumab. Diagn Interv Imaging 2020;101:323-4.

14. Michot JM, Albiges L, Chaput N, et al. Tocilizumab, an anti-IL6 receptor antibody, to treat Covid-19-related respiratory failure: a case report. Ann Oncol 2020;31:961-4.

15. Zhang X, Song K, Tong F, et al. First case of COVID-19 in a patient with multiple myeloma successfully treated with tocilizumab. Blood Adv 2020;4:1307-10.

16. Antwi-Amoabeng D, Kanji Z, Ford B, Beutler BD, Riddle MS, Siddiqui F. Clinical outcomes in COVID-19 patients treated with tocilizumab: an individual patient data systematic review. J Med Virol 2020 May 21 (Epub ahead of print).

17. Xu X, Han M, Li T, et al. Effective treatment of severe COVID-19 patients with tocilizumab. Proc Natl Acad Sci U S A 2020;117:10970-5. 
medRxiv preprint doi: https://doi.org/10.1101/2020.08.27.20183442; this version posted September $12,2020$. The copyright holder for this preprint (which was not certified by peer review) is the author/funder, who has granted medRxiv a license to display the preprint in It is made available under a CC-BY-NC-ND 4.0 International license .

18. Luo P, Liu Y, Qiu L, Liu X, Liu D, Li J. Tocilizumab treatment in COVID-19: a single center experience. J Med Virol 2020;92:814-8.

19. Mastroianni A, Greco S, Apuzzo G, et al. Subcutaneous tocilizumab treatment in patients with severe COVID-19-related cytokine release syndrome: an observational cohort study. EClinicalMedicine 2020:100410.

20. Kaye AG, Siegel R. The efficacy of IL-6 inhibitor tocilizumab in reducing severe COVID-19 mortality: a systematic review. medRxiv 2020:2020.07.10.20150938.

21. Guaraldi G, Meschiari M, Cozzi-Lepri A, et al. Tocilizumab in patients with severe COVID-19: a retrospective cohort study. Lancet Rheumatol 2020;2:e474-e84.

22. Horby P, Lim WS, Emberson JR, et al. Dexamethasone in hospitalized patients with Covid-19_preliminary report. N Engl J Med 2020 July 17 (Epub ahead of print).

23. Beigel JH, Tomashek KM, Dodd LE, et al. Remdesivir for the treatment of Covid-19Preliminary Report. N Engl J Med 2020 May 22 (Epub ahead of print).

24. Wiersinga WJ, Rhodes A, Cheng AC, Peacock SJ, Prescott HC. Pathophysiology, transmission, diagnosis, and treatment of coronavirus disease 2019 (COVID-19): a review. JAMA 2020 July 10 (Epub ahead of print). 
medRxiv preprint doi: https://doi.org/10.1101/2020.08.27.20183442; this version posted September $12,2020$. The copyright holder for this preprint (which was not certified by peer review) is the author/funder, who has granted medRxiv a license to display the preprint in It is made available under a CC-BY-NC-ND 4.0 International license .

\section{TABLES AND FIGURES}

Table 1. Baseline Demographics and Disease Characteristics

\begin{tabular}{|c|c|c|}
\hline & $\begin{array}{c}\text { Tocilizumab } \\
\mathbf{N}=294\end{array}$ & $\begin{array}{c}\text { Placebo } \\
\mathrm{N}=144\end{array}$ \\
\hline Male, n (\%) & $205(69.7)$ & $101(70.1)$ \\
\hline Age, years, mean (SD) & $60.9(14.6)$ & $60.6(13.7)$ \\
\hline $\begin{array}{l}\text { Age category, years, } \mathrm{n}(\%) \\
18-64 \\
65-84 \\
\geq 85\end{array}$ & $\begin{array}{c}163(55.4) \\
117(39.8) \\
14(4.8) \\
\end{array}$ & $\begin{array}{c}81(56.3) \\
60(41.7) \\
3(2.1) \\
\end{array}$ \\
\hline Weight, kg, mean (SD) & $88.9(23.6)$ & $\begin{array}{c}\mathrm{n}=143 \\
88.1(24.3)\end{array}$ \\
\hline $\begin{array}{l}\text { Race, } \mathrm{n}(\%) \\
\text { American Indian or Alaska Native } \\
\text { Asian } \\
\text { Black or African American } \\
\text { Native Hawaiian or other Pacific Islander } \\
\text { White } \\
\text { Multiple } \\
\text { Unknown }\end{array}$ & $\begin{array}{c}8(2.7) \\
28(9.5) \\
40(13.6) \\
3(1.0) \\
176(59.9) \\
0 \\
39(13.3) \\
\end{array}$ & $\begin{aligned} & 5(3.5) \\
& 10(6.9) \\
& 26(18.1) \\
& 5(3.5) \\
& 76(52.8) \\
& 1(0.7) \\
& 21(14.6) \\
&\end{aligned}$ \\
\hline $\begin{array}{l}\text { Region, } \mathrm{n}(\%) \\
\text { Europe } \\
\text { North America } \\
\end{array}$ & $\begin{array}{l}120(40.8) \\
174(59.2) \\
\end{array}$ & $\begin{array}{l}59(41.0) \\
85(59.0) \\
\end{array}$ \\
\hline NEWS2 score, mean (SD) & $7.1(3.0)$ & $7.0(3.0)$ \\
\hline $\begin{array}{l}\text { Ordinal scale for clinical status, n (\%) } \\
2 \\
3 \\
4 \\
5 \\
6\end{array}$ & $\begin{array}{l}9(3.1) \\
78(26.5) \\
94(32.0) \\
45(15.3) \\
68(23.1)\end{array}$ & $\begin{array}{l}6(4.2) \\
44(30.6) \\
39(27.1) \\
15(10.4) \\
40(27.8)^{*}\end{array}$ \\
\hline $\begin{array}{l}\text { Interleukin-6, ng/ } \mathrm{L}^{\dagger} \\
\text { Mean (SD) } \\
\text { Median (range) }\end{array}$ & $\begin{array}{c}\mathrm{n}=233 \\
201.9(418.4) \\
88.1(3.1 \text { to } 4020) \\
\end{array}$ & $\begin{array}{c}\mathrm{n}=100 \\
195.4(368.2) \\
71.2(3.1 \text { to } 2810) \\
\end{array}$ \\
\hline $\begin{array}{l}\text { CRP, mg/L } \\
\text { Mean (SD) } \\
\text { Median (range) }\end{array}$ & $\begin{array}{c}\mathrm{n}=237 \\
168.4(101.4) \\
157.2(1.1 \text { to } 446.6)\end{array}$ & $\begin{array}{c}\mathrm{n}=125 \\
172.6(114.0) \\
150.3(1.6 \text { to } 499.6)\end{array}$ \\
\hline $\begin{array}{l}\text { Ferritin, } \mathrm{pmol} / \mathrm{mL} \\
\text { Mean (SD) } \\
\text { Median (range) }\end{array}$ & $\begin{array}{c}\mathrm{n}=241 \\
6891(106736) \\
2.3(0.0 \text { to } 1657000)\end{array}$ & $\begin{array}{c}\mathrm{n}=128 \\
4027(45431) \\
2.2(0.1 \text { to } 514000)\end{array}$ \\
\hline Mechanical ventilation, $\mathrm{n}(\%)^{\ddagger}$ & $111(37.8)$ & $54(37.5)$ \\
\hline $\begin{array}{l}\text { Days on mechanical ventilation before } \\
\text { baseline } \S \text { among patients on mechanical } \\
\text { ventilation at randomization } \\
\text { Mean (SD) } \\
\text { Median (range) }\end{array}$ & $\begin{array}{c}\mathrm{n}=107 \\
5.1(5.5) \\
3.0(0.0 \text { to } 28.0)\end{array}$ & $\begin{array}{c}4.3(4.5) \\
3.0(0.0 \text { to } 20.0)\end{array}$ \\
\hline Symptoms at diagnosis, n (\%) & & \\
\hline
\end{tabular}




\begin{tabular}{|c|c|c|}
\hline $\begin{array}{l}\text { Fever } \\
\text { Cough } \\
\text { Shortness of breath } \\
\text { GI symptoms } \\
\text { Headache } \\
\text { Fatigue }\end{array}$ & $\begin{array}{l}193(65.6) \\
216(73.5) \\
213(72.4) \\
96(32.7) \\
37(12.6) \\
91(31.0)\end{array}$ & $\begin{array}{l}98(68.1) \\
102(70.8) \\
93(64.6) \\
41(28.5) \\
21(14.6) \\
44(30.6)\end{array}$ \\
\hline $\begin{array}{l}\text { Comorbidities, } n(\%)^{\|} \\
\geq 1 \text { comorbidity } \\
\text { Obesity } \\
\text { Diabetes } \\
\text { Cardiovascular impairment } \\
\text { Hypertension } \\
\text { Hepatic impairment } \\
\text { Chronic lung disease } \\
\end{array}$ & $\begin{array}{c}231(78.6) \\
63(21.4) \\
105(35.7) \\
88(29.9) \\
178(60.5) \\
6(2.0) \\
49(16.7)\end{array}$ & $\begin{array}{c}124(86.1) \\
27(18.8) \\
62(43.1) \\
35(24.3) \\
94(65.3) \\
2(1.4) \\
22(15.3) \\
\end{array}$ \\
\hline $\begin{array}{l}\text { Days from first COVID-19 symptom } \\
\text { Mean (SD) } \\
\text { Median (range) }\end{array}$ & $\begin{array}{c}\mathrm{n}=291 \\
12.1(6.6) \\
11.0(1.0 \text { to } 49.0)\end{array}$ & $\begin{array}{c}\mathrm{n}=143 \\
11.4(6.9) \\
10.0(2.0 \text { to } 50.0)\end{array}$ \\
\hline $\begin{array}{l}\text { Steroid use at baseline or any time during } \\
\text { the study, } \mathrm{n}(\%)^{\Phi}\end{array}$ & $106(36.1)$ & $79(54.9)$ \\
\hline $\begin{array}{l}\text { Antiviral treatment at baseline or any time } \\
\text { during the study, } n(\%)\end{array}$ & 87 (29.6) & $51(35.4)$ \\
\hline $\begin{array}{l}\text { Convalescent plasma treatment at baseline } \\
\text { or during the study, } \mathrm{n}(\%)\end{array}$ & $10(3.4)$ & $6(4.2)$ \\
\hline
\end{tabular}

"Includes a patient who died on study day 1 (baseline ordinal category 7) but who was in category 6

on day 1 before death.

†Values below the lower limit of quantitation of $3.12 \mathrm{ng} / \mathrm{L}$ were set at this value.

${ }^{\ddagger}$ At randomization (for stratification).

${ }^{\S}$ Counted from recorded intubation start date to the day before study day 1 (inclusive). The earliest start date was used if multiple procedures were recorded. Patients first intubated on study day 1 were assigned zero days on mechanical ventilation before baseline.

'Medical history conditions were coded using the Medical Dictionary for Regulatory Activities, version 23.0.

"Baseline defined as study days -7 to 1 (first dose of study treatment). Steroid use included only systemic use, and antiviral treatment included lopinavir-ritonavir, remdesivir, lopinavir, ritonavir, chloroquine, hydroxychloroquine, and hydroxychloroquine sulfate. 
medRxiv preprint doi: https://doi.org/10.1101/2020.08.27.20183442; this version posted September $12,2020$. The copyright holder for this preprint (which was not certified by peer review) is the author/funder, who has granted medRxiv a license to display the preprint in It is made available under a CC-BY-NC-ND 4.0 International license .

Table 2. Efficacy Endpoints (modified-intention-to-treat population)

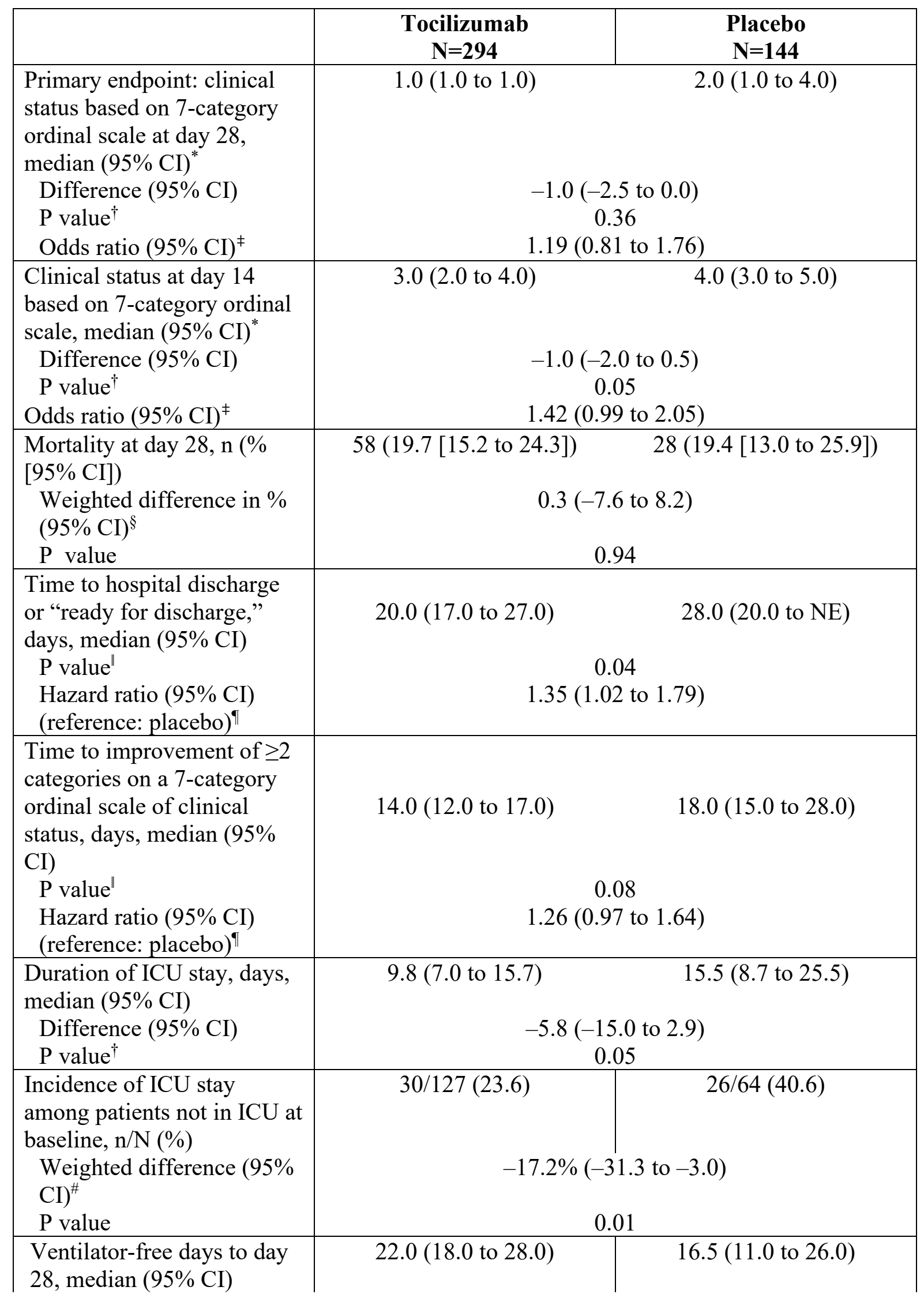




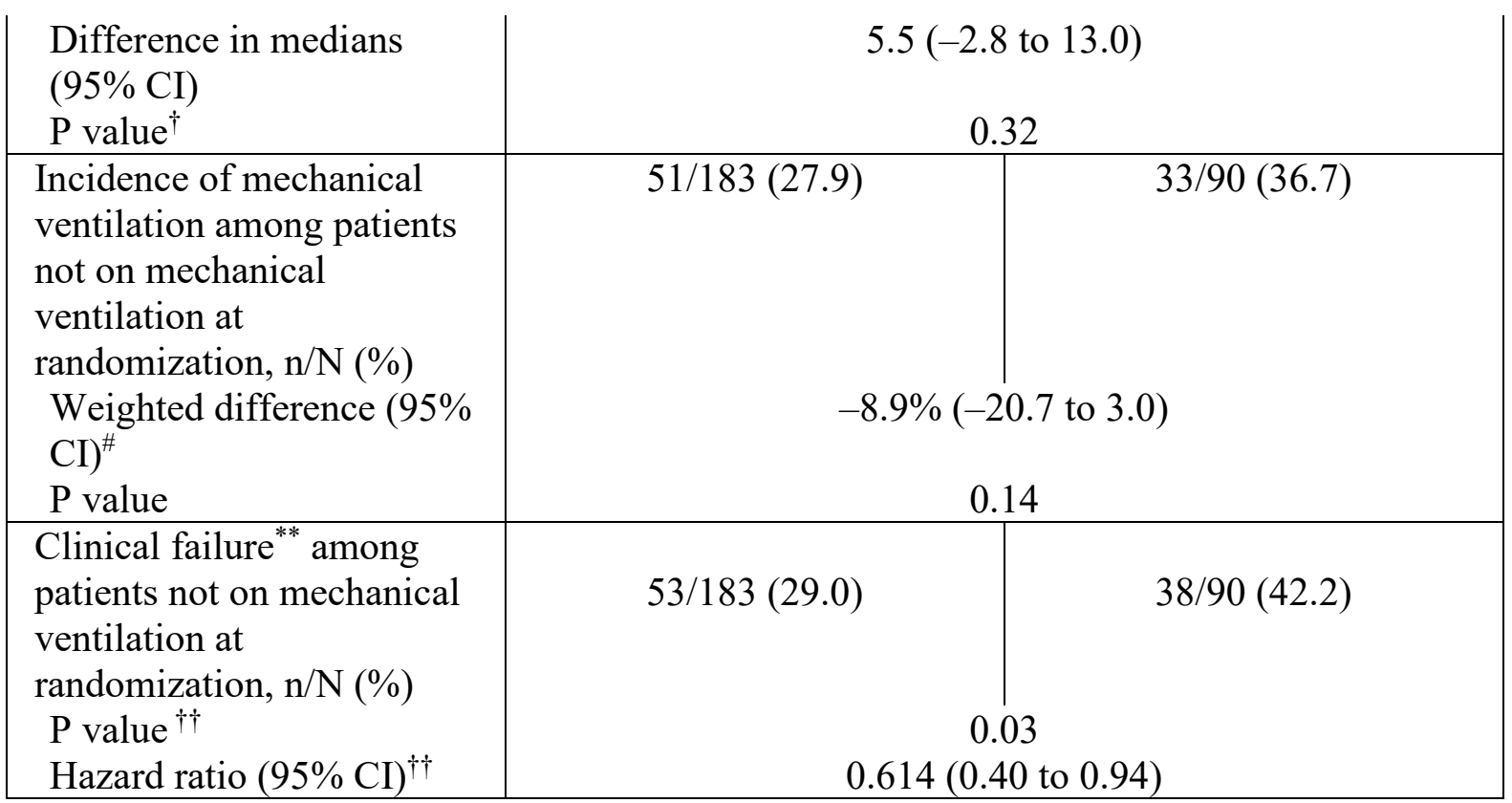

*7-category ordinal scale: 1 , discharged or ready for discharge; 2 , non-ICU hospital ward, not

requiring supplemental oxygen; 3, non-ICU hospital ward, requiring supplemental oxygen; 4, ICU or non-ICU hospital ward, requiring noninvasive ventilation or high-flow oxygen; 5, ICU, requiring intubation and mechanical ventilation; 6, ICU, requiring ECMO or mechanical ventilation and additional organ support; 7 , death.

${ }^{\dagger} \mathrm{P}$ value based on van Elteren test stratified by region and mechanical ventilation at randomization.

${ }^{\ddagger}$ Odds ratio based on ordinal logistic regression analysis adjusted for region and mechanical ventilation at randomization.

${ }^{\$} \mathrm{P}$ value based on extended Cochran-Mantel-Haenszel test stratified by region and mechanical ventilation at randomization.

"P value based on log-rank test stratified by region and mechanical ventilation at randomization.

${ }^{q}$ Cox proportional hazards model stratified by region and mechanical ventilation at randomization.

${ }^{\#}$ Weighted difference in percentages calculated using the Cochran-Mantel-Haenszel test stratified by region at randomization.

${ }^{* *}$ Death, withdrawal during hospitalization, transfer to ICU, or requirement for invasive mechanical ventilation within 28 days of baseline.

${ }^{\dagger}$ Stratified log-rank test for $\mathrm{P}$ value and Cox proportional hazards model for hazard ratio, including stratification by region at randomization. 
medRxiv preprint doi: https://doi.org/10.1101/2020.08.27.20183442; this version posted September $12,2020$. The copyright holder for this preprint (which was not certified by peer review) is the author/funder, who has granted medRxiv a license to display the preprint in It is made available under a CC-BY-NC-ND 4.0 International license .

ECMO, extracorporeal membrane oxygenation; ICU, intensive care unit; NE, nonevaluable. 
Table 3. Safety to day 28 (safety population)

\begin{tabular}{|c|c|c|}
\hline & $\begin{array}{c}\text { Tocilizumab } \\
\mathrm{N}=295\end{array}$ & $\begin{array}{c}\text { Placebo } \\
N=143\end{array}$ \\
\hline $\begin{array}{l}\text { Patients with } \geq 1 \text { adverse event, } n(\%) \\
\text { Adverse events, } n\end{array}$ & $\begin{array}{c}228(77.3) \\
778 \\
\end{array}$ & $\begin{array}{c}116(81.1) \\
360\end{array}$ \\
\hline $\begin{array}{l}\text { Patients with } \geq 1 \text { serious adverse event } \\
\text { Serious adverse events, } \mathrm{n}\end{array}$ & $\begin{array}{c}103(34.9) \\
160\end{array}$ & $\begin{array}{c}55(38.5) \\
101\end{array}$ \\
\hline Patients who died, n (\%) & $58(19.7)$ & $28(19.6)$ \\
\hline \multicolumn{3}{|c|}{ Patients with adverse events of special interest, $\mathrm{n}(\%)$} \\
\hline Infections & $113(38.3)$ & $58(40.6)$ \\
\hline Serious infections & $62(21.0)$ & $37(25.9)$ \\
\hline Opportunistic infections ${ }^{*}$ & $1(0.3)$ & $1(0.7)$ \\
\hline Medically confirmed malignancies & $1(0.3)$ & 0 \\
\hline Hypersensitivity $^{\dagger}$ & $19(6.4)$ & $4(2.8)$ \\
\hline Anaphylaxis per Sampson criteria & 0 & $1(0.7)$ \\
\hline Hepatic events & $5(1.7)$ & $3(2.1)$ \\
\hline Laboratory criteria of Hy's Law ${ }^{\ddagger}$ & $3(1.0)$ & $3(2.1)$ \\
\hline Myocardial infarction & $3(1.0)$ & $2(1.4)$ \\
\hline Stroke & $3(1.0)$ & $2(1.4)$ \\
\hline Bleeding events & $45(15.3)$ & $16(11.2)$ \\
\hline Serious bleeding events & $13(4.4)$ & $5(3.5)$ \\
\hline \multicolumn{3}{|c|}{ Serious infections ${ }^{\S}$ reported in $>1 \%$ of patients in either treatment arm } \\
\hline COVID-19 (causing death) & $39(13.2)$ & $18(12.6)$ \\
\hline Septic shock & $7(2.4)$ & $6(4.2)$ \\
\hline Pneumonia & $7(2.4)$ & $4(2.8)$ \\
\hline Pneumonia bacterial & $6(2.0)$ & $2(1.4)$ \\
\hline Sepsis & $3(1.0)$ & $4(2.8)$ \\
\hline Bacteremia & $2(0.7)$ & $3(2.1)$ \\
\hline
\end{tabular}

Data are number (\%) of patients unless stated otherwise.

${ }^{*}$ Candida sepsis in the tocilizumab arm and respiratory moniliasis in the placebo arm. 
medRxiv preprint doi: https://doi.org/10.1101/2020.08.27.20183442; this version posted September 12, 2020. The copyright holder for this preprint (which was not certified by peer review) is the author/funder, who has granted medRxiv a license to display the preprint in It is made available under a CC-BY-NC-ND 4.0 International license .

${ }^{\dagger}$ Defined as all events that occurred during or within 24 hours of the infusion and were not assessed as "unrelated to study treatment" by the investigator, regardless of whether they were clinically consistent with hypersensitivity.

${ }^{\ddagger}$ Alanine aminotransferase or aspartate aminotransferase levels $>3 \times$ upper limit of normal with either bilirubin level $>2 \times$ upper limit of normal.

${ }^{\S}$ Reported by Medical Dictionary for Regulatory Activities preferred term. 
medRxiv preprint doi: https://doi.org/10.1101/2020.08.27.20183442; this version posted September $12,2020$. The copyright holder for this preprint (which was not certified by peer review) is the author/funder, who has granted medRxiv a license to display the preprint in It is made available under a CC-BY-NC-ND 4.0 International license .

\section{Figure 1. Patient disposition.}

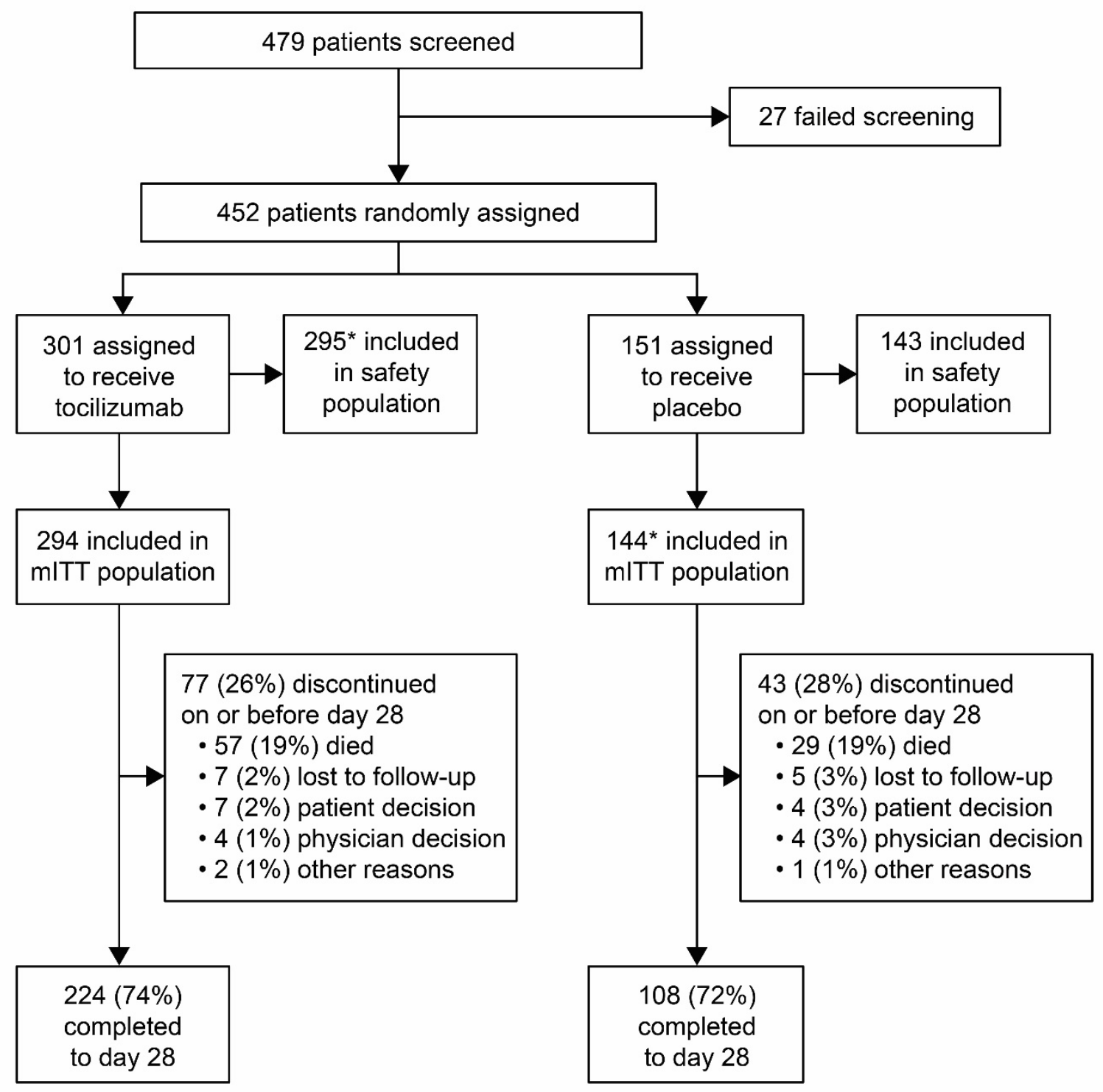

*One patient randomly assigned to the placebo arm was treated with tocilizumab; this patient was included in the tocilizumab group for the safety population and in the placebo group for the mITT population.

mITT population, modified-intention-to-treat population, which included all randomized patients who received study treatment. 
medRxiv preprint doi: https://doi.org/10.1101/2020.08.27.20183442; this version posted September $12,2020$. The copyright holder for this preprint (which was not certified by peer review) is the author/funder, who has granted medRxiv a license to display the preprint in It is made available under a CC-BY-NC-ND 4.0 International license .

Figure 2. (A) time to improvement of $\geq 2$ ordinal scale categories relative to baseline, (B) time to hospital discharge/ready for discharge to day 28 , and (C) clinical status assessed using 7-category ordinal scale at day 28 according to baseline ordinal scale category (modifiedintention-to-treat population for all analyses).

A

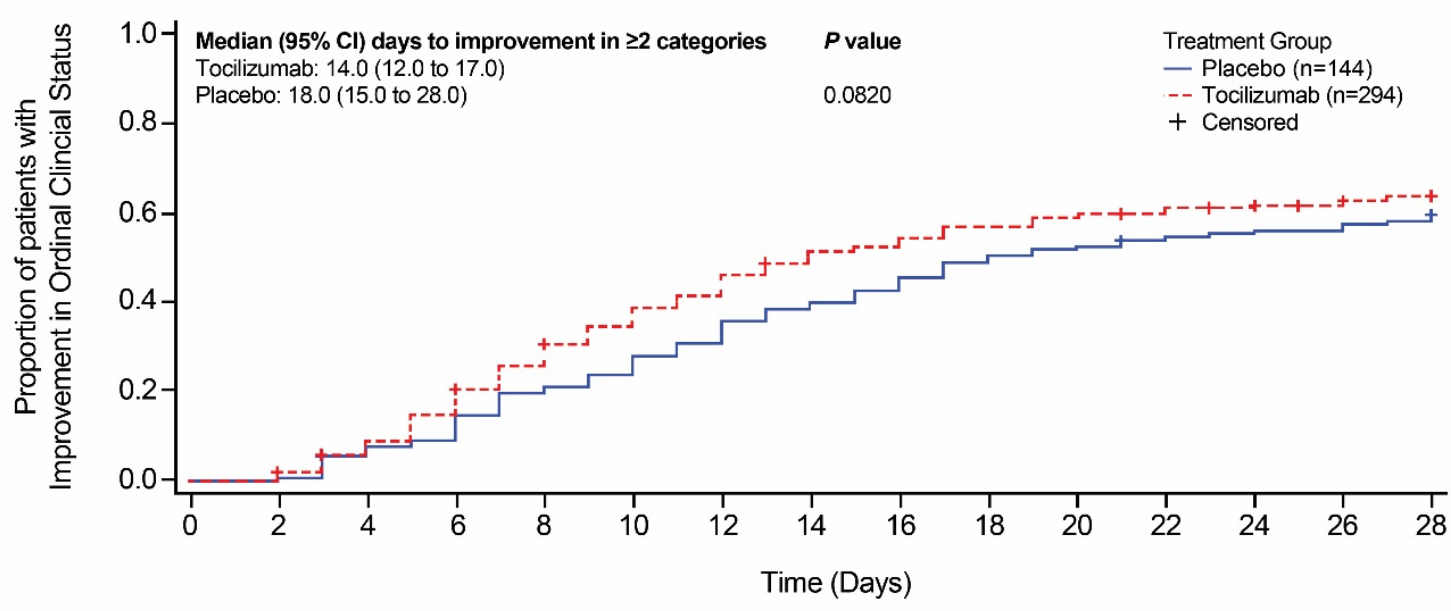

Patients remaining at risk

$\begin{array}{lccccccccccccccc}\text { Placebo } & 144 & 144 & 135 & 130 & 115 & 109 & 99 & 88 & 82 & 73 & 69 & 65 & 63 & 62 & 59 \\ \text { Tocilizumab } & 294 & 294 & 275 & 248 & 216 & 189 & 169 & 148 & 137 & 124 & 118 & 115 & 110 & 107 & 99\end{array}$

B

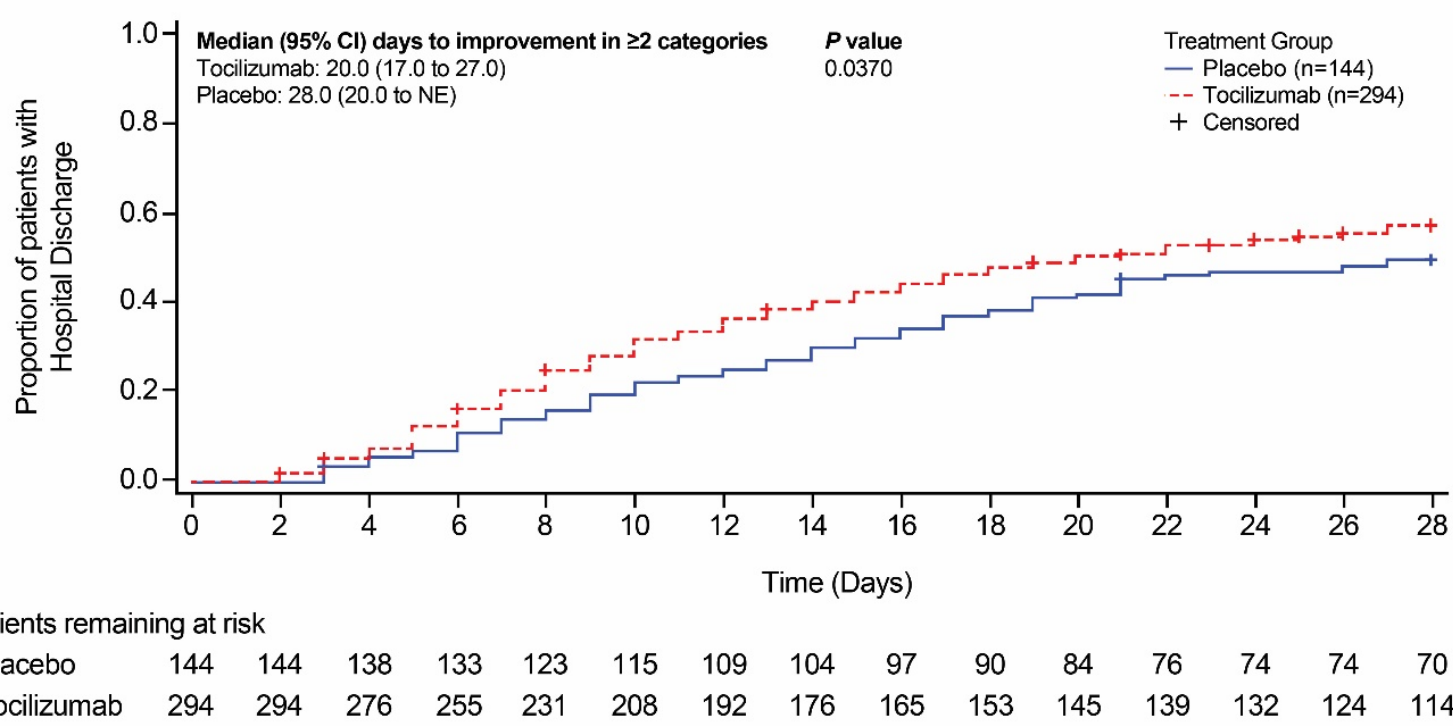


C
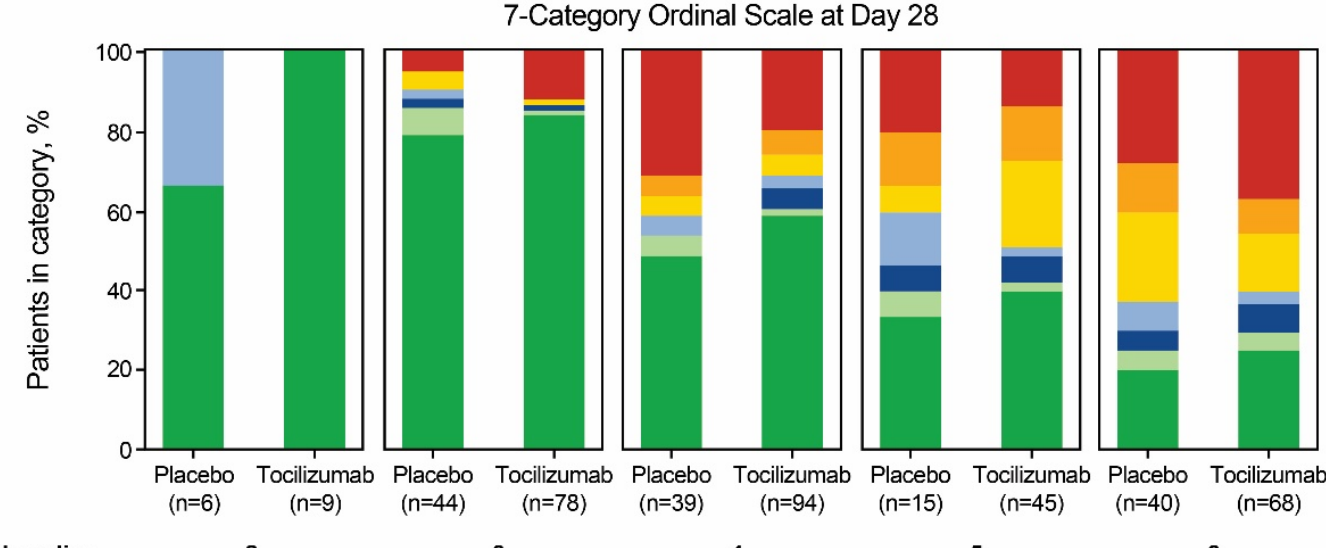

Ordinal category at baseline

2

3

4

6

\begin{tabular}{|llllllllllll} 
7-Category Ordinal Scale & $\square 1$ & $\square$ & $\square$ & $\square$ & 4 & 5 & $\square 6$ & $\square 7$
\end{tabular}

Ordinal category at day

7

6

5

4

3

2

1

OR

$(95 \% \mathrm{Cl})$

Median
$(95 \% \mathrm{Cl})$

Difference in medians $(95 \% \mathrm{Cl})$
Overall

$\begin{array}{cc}\begin{array}{c}\text { Placebo } \\ \mathbf{n}=144\end{array} & \begin{array}{c}\text { Tocilizumab } \\ \mathbf{n}=294\end{array} \\ 28(19.4) & 58(19.7) \\ 9(6.3) & 18(6.1) \\ 14(9.7) & 26(8.8) \\ 10(6.9) & 6(2.0) \\ 4(2.8) & 14(4.8) \\ 8(5.6) & 6(2.0) \\ 71(49.3) & 166(56.5) \\ (0.81 \text { to } 1.76) \\ 2.0 & 1.0 \\ (1.0 \text { to } 4.0) & (1.0 \text { to } 1.0)\end{array}$

$$
(-2.5 \text { to } 0.0)
$$

2
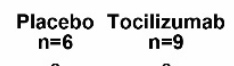

00

$0 \quad 0$

$0 \quad 0$

2 (33.3) 0

$0 \quad 0$

$0 \quad 0$

$4(66.7) \quad 9(100)$

NE

$\begin{array}{cc}1.0 & 1.0 \\ (1.0 \text { to } 4.0) & \text { (1.0 to } 1.0)\end{array}$

0.0
$(-3.0$ to 0.0$)$
Ordinal category at baseline

3
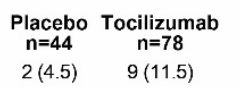

00

$2(4.5) \quad 1(1.3)$

1 (2.3) $\quad 0$

$1(2.3) \quad 1(1.3)$

$3(6.8) \quad 1(1.3)$

$35(79.6) \quad 66(84.6)$

1.27
$(0.48$ to 3.37$)$

$\begin{array}{cc}1.0 & 1.0 \\ (1.0 \text { to } 1.0) & (1.0 \text { to } 1.0)\end{array}$

\begin{tabular}{cc}
$\begin{array}{c}\text { Placebo } \\
\mathrm{n}=39\end{array}$ & $\begin{array}{c}\text { Tocilizumab } \\
\mathrm{n}=94\end{array}$ \\
$12(30.8)$ & $18(19.1)$ \\
$2(5.1)$ & $6(6.4)$ \\
$2(5.1)$ & $5(5.3)$ \\
$2(5.1)$ & $3(3.2)$ \\
0 & $5(5.3)$ \\
$2(5.1)$ & $1(1.1)$ \\
$19(48.7)$ & $56(59.6)$ \\
\multicolumn{2}{c}{1.59} \\
$(0.78$ to 3.24$)$
\end{tabular}

5

5

6

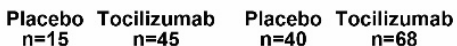

$n=45 \quad n=40$

$3(20.0) \quad 6(13.3) \quad 11(27.5) \quad 25(36.8)$

$2(13.3) \quad 6(13.3) \quad 5(12.5) \quad 6(8.8)$

$1(6.7) \quad 10(22.2) \quad 9(22.5) \quad 10(14.7)$

$2(13.3) \quad 1(2.2) \quad 3(7.5) \quad 2(2.9)$

$\begin{array}{llll}1(6.7) & 3(6.7) & 2(5.0) & 5(7.4)\end{array}$

$1(6.7) \quad 1(2.2) \quad 2(5.0) \quad 3(4.4)$

$5(33.3) \quad 18(40.0) \quad 8(20.0) \quad 17(25.0)$

$\begin{array}{cc}1.10 & 0.88 \\ (0.38 \text { to } 3.15) & (0.44 \text { to } 1.78)\end{array}$

$\begin{array}{llllll}2.0 & 1.0 & 4.0 & 4.0 & 5.0 & 5.0\end{array}$

$\begin{array}{cccc}0.0 & -1.0 & 0.0 & 0.0 \\ (0.0 \text { to } 0.0) & (-5.0 \text { to } 0.0) & (-3.5 \text { to } 4.0) & (-1.0 \text { to } 2.0)\end{array}$

7-category ordinal scale: 1, discharged or ready for discharge; 2 , non-ICU hospital ward, not requiring supplemental oxygen; 3, non-ICU hospital ward requiring supplemental oxygen; 4, ICU or non-ICU hospital ward, requiring noninvasive ventilation or high-flow oxygen; 5, ICU, requiring intubation and mechanical ventilation; 6, ICU, requiring ECMO or mechanical ventilation and additional organ support; 7 , death.

(A, B) Data are plotted as one minus the Kaplan-Meier estimator. Patients who discontinued or were lost to follow-up for any reason before the event were censored at their last ordinal scale assessment. Patients who died were censored at day 28. (C) Death or hospital discharge were carried forward, including deaths that occurred after withdrawal. Any remaining missing data were imputed using the last postbaseline observation carried forward method. 
medRxiv preprint doi: https://doi.org/10.1101/2020.08.27.20183442; this version posted September $12,2020$. The copyright holder for this preprint (which was not certified by peer review) is the author/funder, who has granted medRxiv a license to display the preprint in It is made available under a CC-BY-NC-ND 4.0 International license.

Category 6 includes a patient who died on study day 1 (ordinal category 7) but was in category 6 on day 1 before receiving study treatment; this patient was not included in the calculation of medians.

NE, not evaluable. 